\title{
RAMÓN LLULL: EL LIBRO DEL AMIGO Y DEL AMADO
}

Versión de Martí Soler*

RESUMEN: Se prepara una nueva edición de El libro del amigo y del amado, de Ramón Llull, del cual -a partir de una pequeña muestra- el traductor nos ilustra sobre la entereza de aquel que dialoga con Dios por medio del amor.

yos

ABSTRACT: A glimpse into the new translation of Ramón Llull's Book of the Lover and the Beloved, showcases how the translator illustrates the strength of one who dialogues with God through love.

PALABRAS CLAVE: Llull, amigo, amado, Dios, amor.

KEY WORDS: Llull, lover, beloved, God, love.

RECEPCIÓN: 04 de mayo de 2010.

APROBACIÓN: 24 de febrero de 2011.

* Escritor. 
CITAM Derechos Reservados.

La reproducción total o parcial de este artículo se podrá hacer si el ITAM otorga la autorización previamente por escrito. 


\section{RAMÓN LLULL: EL LIBRO DEL AMIGO Y DEL AMADO}

Ramon Llull o Raimundus Lulius, como firmaba sus obras en latín (Raimundo Lulio en trascripción española), filósofo y beato mallorquín del siglo XIII, sigue siendo motivo de elucubraciones y estudio entre académicos y poetas. $\mathrm{Su}$ Llibre d'amic e amat, que es con toda seguridad un capítulo de la novela Blanquerna, y acaso preámbulo de su Llibre de contemplació, o preparación para su lectura, expresa la entereza de quien dialoga con Dios por medio del amor. Pero ese diálogo amoroso proviene del sentimiento (de la fe) y del entendimiento. Razonar mediante el amor es una de las más duras tareas a las que se puede enfrentar el ser humano, y Llull va elaborando su pasión a lo largo de un racimo apretado de pensamientos en una precisa elaboración que nos lleva de la mano como un lazarillo hasta su culminación. Y esta culminación no es otra que la que deriva de una secuencia de breves textos que, a veces, ser o no ser, en ese diálogo entre el amigo y el amado, aquél incurre incluso en enfrentamientos "por desamor", que desembocan en la duda y en el dolor de ser cristiano y en el dejar de serlo "por desamor". Pero "cada versículo basta para contemplar a Dios un día entero", afirma Llull en su prólogo. Nuestra tarea al traducirlo para el público mexicano ha surgido del descubrimiento de su actualidad en un mundo esquizofrénico.

Nuestra traducción se basa en la edición crítica de Albert Soler i Llopart para "Els Nostres Clàssics" de la Fundació Jaume I (Barcelona, Editorial Barcino, 1995). En esta edición, el Libro consta de 357 
versículos (y nosotros seguimos su numeración), aunque Ramon Llull afirma que “departí en aytants versses com ha dies en l'ayn”. El autor de esta edición nos aclara que Blanquerna "no puede ser posterior a 1289 y que, con toda probabilidad, la terminó [Llull] en Montpellier hacia 1283 [...] por lo que el Llibre d'amic e amat debe de haberse escrito alrededor de esta fecha". La edición de Blanquerna de Editorial Porrúa (México, 1990) reedita la primera traducción -anónima- al español (Palma de Mallorca, 1749) con algunas correcciones, supresiones de versículos apócrifos y agregados necesarios. Nosotros estamos preparando una nueva traducción que aparecerá en Libros del Umbral y de la cual forma parte este adelanto. 


\section{EL LIBRO DEL AMIGO Y DEL AMADO}

\section{2}

Los caminos por los que el amigo busca a su amado son largos, peligrosos, poblados de dudas, suspiros y llantos, pero iluminados por el amor.

\section{7}

Preguntaron al amigo acerca de qué es causa, y dijo que causa es placer en la penitencia, entendimiento en la conciencia, esperanza en la paciencia, salud en la abstinencia, consuelo en el recuerdo, amor en la diligencia, lealtad en la vergüenza, riqueza en la pobreza, y paz en la obediencia y guerra en la malevolencia.

\section{7}

Yacía el amigo en un lecho de amor. Las sábanas eran de placeres, el cobertor era de sufrimientos y la almohada de llanto.

Y se preguntaba si la tela de la almohada era la misma que la tela de las sábanas o la del cobertor.

\section{4}

El amado le preguntó al amigo qué era el amor. Respondió éste que era la presencia de las facciones y de las palabras del amado en un corazón deseoso de amar, y el desfallecimiento debido a ese deseo y a los llantos en su corazón de amigo. Amor es un hervor de audacia y de temor provocado por el fervor. Amor es voluntad final de desear al amado. $\mathrm{Y}$ amor es aquello que hace que el amigo muera cuando oye cantar las bellezas de su amado. 
MARTÍ SOLER

-Y amor es lo que me da muerte y lo que todos los días aparece en mi voluntad.

\section{8}

Amor es un mar atribulado de olas y de vientos, que no tiene puerto ni ribera.

Perece el amigo en el mar y en su peligro perecen sus tormentos y nacen sus perfecciones.

\section{4}

Decía el amigo que la ciencia infusa provenía de la voluntad, de la devoción y de la oración, y que la ciencia adquirida provenía del estudio y del entendimiento.

Y por eso se discute qué ciencia prefiere el amigo, o cuál le es más agradable y cuál es mayor en el amigo.

Amores surgen de amores y pensamientos de sufrimientos y llantos por los sufrimientos. Y los amores entran en los amores y los pensamientos en los llantos y los sufrimientos en los suspiros.

Y el amado contempla a su amigo, que por su amor pasa por todas estas tribulaciones.

\section{0}

Tuvo el amigo hambre, sed, calor y frío, pobreza y desnudez, enfermedad y tribulaciones, y habría fallecido si no poseyera el recuerdo de su amado, que lo sanó con la esperanza y el recuerdo y con la renuncia de este mundo y con el menosprecio por los vituperios de la gente. 
Se contemplaba el amigo a sí mismo para volverse espejo en el cual ver a su amado. Y contemplaba a su amado para volverse espejo en el que tuviera conocimiento de sí mismo.

Y la pregunta es a cuál de los dos espejos se acercaba más su entendimiento. 
CITAM Derechos Reservados.

La reproducción total o parcial de este artículo se podrá hacer si el ITAM otorga la autorización previamente por escrito. 